\title{
E-OPPIMISESTA TEHOKKUUTTA LUOTTAMUSMIESTEN KOULUTUKSEEN
}

\author{
Luottamusmiesten täytyy hallita hyvin työelämän lait, sopimukset ja \\ säädökset.Suuren tietomäärän takia perinteiset koulutusjaksot ovat \\ pitkiä ja raskaita. Uuden tiedon hallintaa voidaan kuitenkin helpottaa \\ verkkokurssien avulla. STTK:n alaisessa palkansaajajärjestö Pardiassa \\ on kokeiltu e-oppimista myönteisin tuloksin.
}

\section{REETTA HARMAJA}

$\mathrm{T}$ Työntekemisen rytmi on kiihtynyt, ja työntekijän irrottaminen työtehtävistään koulutusta varten on yhä vaikeampaa.

- Halusimme kehittää koulutuksen, jossa luottamusmiesten työpaikalta poissaoloaika olisi mahdollisimman lyhyt, ja samalla pystyisimme viemään koko ohjelman läpi tehokkaasti. Lähiopetusjaksot ovat hyviä, mutta niissä kaadetaan ämpärillä tietoa. Opetettavat asiat eivät välttämättä jää mieleen, jolloin koulutuksen tehokkuus voidaan kyseenalaistaa, kertoo Pardian neuvottelupäällikkö Kauko Passi.

- Verkkokurssilla työ eli oppiminen teetetään opiskelijalla. Samalla mahdollisuudet omaksua uutta tietoa ovat mahdollisimman hyvät, sillä opiskelija voi itse vaikuttaa oppimisajankohtaanja paikkaan. Yhteisissä tapaamisissa voidaan hankittua tietoa syventää ja oppia muita taitoja, kuvaa Passi.

$\mathrm{P}$ ardia on 23 liiton järjestö. Liittoihin kuuluu kaikkiaan yli 500 jäsenyhdistystä ja noin 80000 jäsentä. Heistä enemmistö työskentelee valtion virastoissa tai laitoksissa ja noin neljännes liikelaitoksissa tai yrityksissä. Suurimpia Pardiaan kuuluvia liittoja ovat Suomen Poliisijärjestöjen liitto sekä Tekniikan ja Tiedon toimihenkilöt. Pardian keskeisin tehtävä on tehdä valtion virkaehtosopimus sekä ala- ja yrityskohtaisia työehtosopimuksia, kun kokonaisvaltainen tulopoliittinen ratkaisu on syntynyt, mutta myös luottamusmieskoulutus on tärkeä osa Pardian toimintaa.

\section{VERKKOPOHJAINEN OPPIMIS- YMPÄRISTÖ VAATII LAADUKKAAN MATERIAALIN JA OHJAUKSEN}

Pardiassa on tehty e-oppimiskokeiluja eri ohjelmilla. Yksi ensimmäisistä piloteista oli osittain verkossa toteutettu Yliopistojen ja tutkimusalan henkilöstöliiton (YHL) luottamusmieskurssi. YHL:n luottamusmieskoulutuksessa monimuoto-opetus rakentui lähiopetuspäivistä ja etätehtävistä. Verkkoympäristössä kurssilaiset pystyivät katsomaan toistensa vastauksia ja keskustelemaan niistä.

Pardian tavoitteena on tuottaa pohja kaikkien liittojen luottamusmieskoulutukselle. Hanketta on konsultoinnut mm. e-oppimisen asiantuntijaorganisaatio R5 Vision, joka kehittää verkkopohjaisia opiskelu- ja työympäristöjä sekä tarjoaa niihin liittyviä palveluita.

- E-oppimisen toimiva toteuttaminen vaatii usean osa-alueen huomioimista. Viimeistelty ohjelmisto eli verkkopohjainen koulutusympäristö on ensimmäinen e-oppimisen järjestämisen edellytys, mutta siitä on hyötyä vasta, kun se yhdistetään laadukkaaseen koulutusmateriaaliin sekä oikeanlaiseen koulutuksen suunnitteluun ja ohjaukseen, toteaa R5 Visionin pedagoginen asiantuntija Anu Vuorento.

\section{VERKKOKURSSIT AUTTAVAT TIEDONHALLINNASSA}

Pardian tavoitteena on löytää opetusmenetelmä, jolla luentopainotteisuutta vähennetään ja kuljetaan kohti tavoitteellista, mielekästä ja tuloksel- 
lista oppimista. Kurssit voidaan toteuttaa monimuoto-opetuksena, johon kuuluu sekä lähi- että etäopetusjaksoja. Verkon avulla opiskelu tuodaan lähemmäksi työn arkea ja siihen liittyviä tarpeita sekä nivotaan koulutusjaksot toisiinsa.

-Tietoverkot on tarkoitus kytkeä opetusprosessiin heti ensimmäisestä luottamusmiespäivästä lähtien. Verkon kautta voidaan tyypillisimmillään opettaa sopimusten sisältöä ja lainsäädäntöä. Neuvottelutaitojen ja esiintymisen kehittäminen edellyttävät kuitenkin myös yhteisiä lähiopetusjaksoja, kertoo Passi.

Verkko-opetuksen tarve on laaja. Tietoa kaipaavat niin luottamusmiehinä aloittavat kuin pääluottamusmiehet, joiden koulutukset ovat perinteisesti kestäneet viikkoja. Pardia pyrkii myös selvittämään, miten e-oppimisympäristö voi toimia vuorovaikutusvälineenä luottamusmiesten ja pääluottamusmiesten välillä.

Passin mukaan useimmat keskusliitot pohtivat tietotekniikan hyödyntämistä koulutuksessa. Hän kehottaa liittoja harkitsemaan yhteisen koulutuksen järjestämistä eri osapuolille.

- Myös työnantajan edustajat, erityisesti henkilöstöjohto, painivat samojen asioiden kanssa. Heidän kanssaan voisi järjestää yhteistä koulutusta, sillä esimerkiksi henkilöstöjohtajan ja pääluottamusmiehen tiedontarpeet ovat osittain samoja. Tarkoituksenamme on tehdä koulutuspohjia, joita voimme tarjota myös työnantajille, kertoo Passi.

Työelämänlainsäädäntö on hyvin laaja, ja tieto usein kirjojen varassa. Internet on erinomainen väline esimerkiksi ajan tasalla olevien tietojen haussa.

- Internet tukee toisaalta koulutettavien luottamusmiesten tarvetta saada yleiskuva lainsäädännöstä ja toisaalta löytää oman työn kannalta olennainen tieto. E-oppimisen etu on myös tiedon helppo räätälöiminen. Esimerkiksi poliisien ja verovirkailijoiden kursseissa on osittain sama sisältö, mutta lisäksi asioita, jotka muuttuvat toimialan ja työn luonteen mukaan, toteaa Passi.

Anu Vuorennon mukaan koko oppimiskäsitys on murroksessa. Verkko-oppimisympäristöt muuttavat koko opetus-opiskelu-oppimisprosessin suunnittelusta arviointiin ekä kouluttajan että opiskelijan kannalta.

- Informaatiotulvassa oppimisessa keskeistä on opiskelijan motivaatio oppia ja keskittyä opiskeluun. Parhaat tulokset syntyvät hyvin ohjatussa vuorovaikutteisessa opiskeluympäristössä muiden opiskelijoiden ja ohjaajan kanssa. Tässä opiskelijan on kuitenkin oivallettava oman roolinsa tiedon kriittisenä käsittelijänä. Oppi ei tule useimmiten valmiina, vaan sitä on itse työstettävä. Myös kouluttajan roolit ovat monimuotoisemmat. Lähiopetuksessa korostuva sisällön asiantuntijarooli saa verkko-opetuksessa rinnalleen muun muassa tutorin, verkottajan, kannustajan, materiaalin tuottajan ja organisoijan roolit. Vaikka kouluttajan rooli on merkittävä opiskeluilmapiirin ja vuorovaikutuksen kannalta, suunnittelusssa on tärkeää miettiä kouluttajalle realistinen rooli ja ohjauksen tavat, jotta kouluttaja ei tukehduta itseään eikä opiskeluyhteisöä haastavassa tehtävässään.

\section{LISÄTIETOJA}

R5 Vision: Anu Vuorento, puh. 09-7743740, sähköposti anu.vuorento@r5vision.com

Pardia: Kauko Passi, puh. 09-13152304, sähköpostikauko.passi@pardia.fi

\section{RAKENNUSLIITON DUUNEX}

akennustyöväenliiton osasto 10 Tampe-
reelta toteutti Siikaranta-opiston tieto- ja
viestintätekniikan opettajan Maarit Fredin ohjauksessa oman työyhteisön kehittämiseen tähdänneen Duunex-oppimisympäristökokeilun. Oppimateriaalina oli myös Kimmo Kevätsalon Minä ja työ -aineisto. Kokemukset on koottu kirjaseksi Työelämän kehittäminen verkossa. Opetushallituksen tukemaa kokeilua pidettiin arvokkaana siksikin, että useammalle tietokoneen, internetin ja sähköpostin maailma oli uutta. Duunexin ansioksi kirjattiin se, että projekti lisäsi osallistujien kykyä jäsentää, tulkita ja dokumentoida työelämän ilmiöitä ja käyttää tietotekniikkaa henkilökohtaisen oppimisen välineenä. Kokeilu lisäsi osallistujien ymmärtämystä Internetin mahdollisuuksista $\mathrm{mm}$. verkkokeskustelussa sekä oman työympäristön tutkimisessa kuvailemalla. Todettiin myös se, että tällaisissa hankkeissa tulee ottaa huomioon ennen muuta oppimisen läheinen yhteys käytännön ongelmien ratkaisemiseen. Toteutuksesta ja tuloksista: Työelämän kehittäminen verkossa -vihko (Rakennustyöväenliitto) sekä rl.osasto10@pp.inet.fi tai maarit.fred @siikaranta.fi. 